\title{
PERBEDAAN SIKLUS MENSTRUASI ANTARA IBU YANG MENGGUNAKAN AKDR DAN ALAT KONTRASEPSI SUNTIK DI DESA BERUK KABUPATEN KARANGANYAR
}

\author{
Oleh : \\ Warsini ${ }^{1}$, Ipung Wulandari ${ }^{2}$,Tri Handayani ${ }^{3}$
}

\begin{abstract}
Introduction: An increase in the rate of population growth in Indonesia is increasingly rapidly. One way to control the rate of population growth is by family planning program (KB). Growing family planning programs are administered by the Government, is also increasingly developing contraceptives, such as pills, IUD, implants, sterilizing men, seterilisasi women, condoms, periodic abstinence and copulation is disconnected. In addition to the function to control the population, AKDR and contraceptive injection had side effects, the most important is related to disorders of menstruation. From the results of a survey in Desa Beruk retrieved data. There are $154 \mathrm{KK}$ which resides and $52 \mathrm{KK}$ are acceptors KB which includes AKDR and contraceptive injection and some of them also complained of experiencing menstrual disorders.

The Purpose: To tell the difference between the mother's menstrual cycle which uses AKDR and contraceptive injection in Desa Beruk Kabupaten Karanganyar.

Methods: This study is a comparative analytical research by design with cross sectional design.

Subjects: Acceptors KB type AKDR and syringe in Desa Beruk Kabupaten Karanganyar amounted to 52 people. The sample in this study is taken based on table Krecjie so obtained the result total sample of 44 people. Sampling simple random way (simple random sampling).

Results: Menstrual cycle most often in AKDR is normal usage with a range between 12 and 28 days, whereas in the use of contraceptive injection cycles most often happens is polimenore with the average cycle is 19 days with a range of 14 to 30 days. Mann Whitney test results was $p=0,032$.

Conclusion: Because the value of $p$ can be inferred then $0.05<$ that there are meaningful differences between the menstrual cycle on the use of AKDR and menstrual cycle use of contraceptive injection.
\end{abstract}

Keywords: the difference, menstrual cycle, contraceptive injection, AKDR

\section{PENDAHULUAN}

Laju pertumbuhan penduduk di Indonesia senantiasa mengalami peningkatan, hal ini tercermin dari hasil sensus penduduk tahun 2010, Indonesia menunjukkan gejala peningkatan penduduk. Jumlah penduduk Indonesia tahun 2010 tercatat 237,6 juta jiwa dengan laju pertumbuhan 1,49 persen pertahun, sementara pada tahun 2008 masih tercatat 288,53 juta jiwa. Laju pertumbuhan penduduk ini jika tetap pada angka tersebut maka, pada tahun 2045 jumlah penduduk Indonesia diperkirakan mencapai 450 juta jiwa. Peningkatan penduduk yang tinggi ini akan mengakibatkan permasalahan jika tidak dikendalikan. Salah satu cara untuk mengendalikan laju pertumbuhan penduduk adalah dengan program Keluarga Berencana (KB). 
Dengan semakin berkembangnya program Keluarga Berencana yang dicanangkan oleh pemerintah, alat kontrasepsi juga semakin berkembang. Berbagai pilihan alat kontrasepsi ditawarkan kepada masyarakat, seperti Alat Kontrasepsi Dalam Rahim (AKDR) dan alat kontrasepsi suntik. Menurut Survei Demografi dan Kesehatan Indonesia (2012) kontrasepsi suntik paling banyak digunakan oleh wanita di Indonesia yaitu sebesar $31,9 \%$, pil KB sebanyak 13,6\%, IUD 3,9\%, implant 3,3\%, sterilisasi pria $0,2 \%$, seterilisasi wanita $3,2 \%$, kondom $1,8 \%$, pantang berkala $1,3 \%$ dan sanggama terputus $2,3 \%$. Selain berfungsi untuk mengendalikan penduduk, AKDR dan alat kontrasepsi suntik mempunyai efek samping, yang paling utama adalah berhubungan dengan gangguan haid. AKDR memiliki efek samping yaitu mengalami perubahan pada pola haid antara lain, lama haid menjadi lebih panjang dan beberapa didahului atau diakhiri oleh perdarahan bercak terlebih dahulu, jumlah haid menjadi lebih banyak dan datangnya haid (siklus) menjadi lebih pendek. (Sulistyawati, 2012) Demikian juga pada pemakaian KB suntik muncul permasalahan, yaitu gangguan pola haid, kenaikan berat badan dan sakit kepala. Gangguan haid yang terjadi tergantung pada lama pemakaian. (Sulistyawati, 2012)

Desa Beruk merupakan salah satu desa yang berada di Kelurahan Beruk Kecamatan Jatiyoso Kabupaten Karanganyar. Dari hasil survei di Posyandu Desa Beruk diperoleh data yaitu terdapat $154 \mathrm{KK}$ yang bertempat tinggal dan $52 \mathrm{KK}$ diantaranya akseptor KB yang meliputi AKDR dan suntik. Terdapat 8 ibu pengguna AKDR yang mengeluhkan pola haidnya dan terdapat 10 ibu pengguna alat kontrasepsi suntik yang juga mengatakan siklus menstruasinya pendek. Sedangkan penelitian di Desa Beruk yang berkaitan dengan siklus menstruasi antara ibu yang menggunakan AKDR dan alat kontrasepsi suntik belum pernah dilakukan. Dari uraian masalah di atas maka penulis tertarik untuk mengetahui "Perbedaan siklus menstruasi antara ibu yang menggunakan AKDR dan alat kontrasepsi suntik".

\section{METODE PENELITIAN}

Penelitian ini merupakan penelitian analitik dengan desain komparatif untuk mengetahui perbedaan siklus menstruasi antara ibu yang menggunakan AKDR dan alat kontrasepsi suntik di Desa Beruk Kabupaten Karanganyar. Sedangkan rencana yang digunakan adalah cross sectional, dengan cara membandingkan siklus menstruasi antara pengguna AKDR dan pengguna alat kontrasepsi suntik. Populasi dalam penelitian ini adalah akseptor KB jenis AKDR dan suntik di Desa Beruk Kabupaten Karanganyar yang berjumlah 52 orang. Dalam penelitian ini peneliti menggunakan teknik sampling acak sederhana (simple random sampling, dengan besar sampel yang dihitung menggunakan tabel Krecjie sehingga didapat sampel sebanyak 44 responden.

\section{HASIL PENELITIAN}

Berdasarkan penelitian yang telah dilakukan mulai 1 Desember 2014 sampai 31 Januari 2015 didapatkan karakteristik responden berdasarkan pemakaian alat kontrasepsi, usia, dan lama pemakaian.

Dari data tentang karakteristik responden berdasarkan pemakaian alat kontrasepsi didapatkan hasil bahwa dari 44 responden yang menggunakan alat kontrasepsi, maka paling banyak adalah pengguna alat kontrasepsi suntik 
yaitu sejumlah 22 responden $(50.00 \%)$, sedangkan pengguna Alat kontrasepsi Dalam Rahim lebih sedikit yaitu sebanyak 22 responden (50.00\%).

Dari data tentang karakteristik responden berdasarkan usia pengguna didapatkan hasil bahwa usia responden pengguna AKDR paling banyak adalah antara $25-30$ tahun yaitu sebanyak 11 responden $(50.00 \%)$, antara $30-35$ tahun sebanyak 9 responden (40.90\%) dan paling sedikit berusia antara $20-25$ tahun yaitu 2 responden (9.10\%).

Sedangkan pada pengguna alat kontrasepsi suntik paling banyak adalah antara 30 - 35 tahun yaitu sebanyak 10 responden (45.45\%), antara 25 - 30 tahun sebanyak 9 responden (40.90\%) dan paling sedikit berusia antara $20-25$ tahun yaitu 3 responden (13.65\%). Sedangkan pada karakteristik responden berdasarkan lama pemakaian didapatkan hasil bahwa lama pemakaian alat kontrasepsi pada responden pengguna AKDR paling banyak adalah antara 5-10 tahun yaitu sebanyak 10 responden $(45.45 \%)$ antara $0-5$ tahun sebanyak 7 responden (31.83\%) dan paling sedikit berusia antara $>10$ tahun yaitu 5 responden (22.72\%).

Sedangkan pada pengguna alat kontrasepsi suntik paling banyak adalah antara 0-5 tahun yaitu sebanyak 10 responden (45.45\%), antara 5-10 tahun sebanyak 8 responden (36.37\%) dan paling sedikit berusia antara $>10$ tahun yaitu 4 responden (18.18\%).

Adapun hasil penelitian tentang siklus menstruasi pada penggunaan AKDR didapatkan dari hasil kuesioner, dan dihitung dengan satuan hari. Siklus tersebut kemudian dikategorikan ke dalam 3 golongan yaitu kategori siklus polimenore jika siklus menstruasi kurang dari 21 hari, termasuk kategori siklus normal jika siklus antara 21-35 hari, dan termasuk kategori siklus oligomenore-amenore jika siklus $>35$ hari.

Siklus menstruasi pada sebagian besar akseptor AKDR adalah normal, yaitu sebanyak 17 responden $(77.3 \%)$, dan polimenore sebanyak 5 responden (22.7\%). Dari tabel di atas dapat pula diketahui bahwa tidak ada responden yang mengalami siklus menstruasi oligomenore-amenore.

Data yang didapatkan kemudian diolah untuk mengetahui distribusinya dengan menggunakan uji Kolmogorov-Smirnov dan didapatkan hasil bahwa nilai $p=0$. 036. Karena nilai $p<0.05$ maka maka dapat disimpulkan bahwa distribusi siklus menstruasi tidak normal. Sehingga dalam penyajian data ini cenderung menggunakan median dan minimum-maksimum sebagai ukuran pemusatan dan penyebaran data, dan mean, modus standar deviasi sebagai pelengkap. Mean pada siklus menstruasi pada pemakaian AKDR adalah 23.91 hari dan termasuk dalam kategori siklus normal. Modus pada siklus menstruasi pada pemakaian AKDR adalah 26 hari. Dengan demikian diketahui bahwa siklus yang paling sering muncul pada pemakaian AKDR adalah kategori siklus normal. Nilai tengah pada siklus pengguna AKDR yaitu 26 hari. Dengan demikian nilai median siklus menstruasi pada pemakaian AKDR termasuk dalam kategori siklus normal. Dari data yang dikelompokkan, didapatkan nilai standar deviasi sebesar 4.86. Siklus menstruasi minimum pada pemakaian AKDR adalah 12 hari dan siklus maksimumnya adalah 28 hari.

Siklus menstruasi pada pemakaian alat kontrasepsi suntik juga didapatkan dari hasil kuesioner, dan dihitung dengan satuan hari. Siklus 
tersebut juga dikategorikan ke dalam 3 golongan yaitu kategori siklus polimenore jika siklus menstruasi kurang dari 21 hari, termasuk kategori siklus normal jika siklus antara 21-35 hari, dan termasuk kategori siklus oligomenore-amenore jika siklus $>35$ hari.

Siklus menstruasi terbanyak pada akseptor alat kontrasepsi suntik adalah polimenore yaitu sebanyak 12 responden $(54.50 \%)$ dan siklus menstruasi normal sebanyak 10 responden $(45.50 \%)$. Dari tabel di atas dapat diketahui pula bahwa pada akseptor alat kontrasepsi suntik tidak ditemukan siklus menstruasi oligemenorea-amenore. Data yang didapatkan kemudian diolah untuk mengetahui distribusinya dengan menggunakan uji Kolmogorov-Smirnov dan didapatkan hasil bahwa nilai $\mathrm{p}=0$. 191. Karena nilai $p>0.05$ maka maka dapat disimpulkan bahwa distribusi data normal.

Mean pada siklus menstruasi pada pemakaian alat kontrasepsi suntik adalah 19 hari dan termasuk dalam kategori siklus polimenore. Modus pada siklus menstruasi pada pemakaian alat kontrasepsi suntik adalah 18 hari. Dengan demikian diketahui bahwa siklus yang paling sering muncul pada pemakaian alat kontrasepsi suntik adalah kategori siklus polimenore. Dari data yang diurutkan didapatkan hasil median yaitu 22.50 hari dan termasuk dalam kategori siklus normal. Dari data yang dikelompokkan, didapatkan nilai standar deviasi sebesar 4.55. Standar deviasi merupakan simpangan nilai individu terhadap nilai rata-rata (mean). Siklus menstruasi minimum pada pemakaian alat kontrasepsi suntik adalah 14 hari dan siklus maksimumnya adalah 30 hari.
Setelah salah satu data tentang siklus menstruasi tersebut diketahui berdistribusi tidak normal maka dianggap tidak memenuhi syarat untuk dilakukan uji statistik parametrik maka peneliti menggunakan uji statistik non parametrik yaitu uji Mann Withney dengan bantuan SPSS versi 18 . didapatkan hasil nilai uji Mann Withney, yaitu $p=0.032$. Karena nilai $\mathrm{p}<0.05$ maka dapat disimpulkan bahwa ada perbedaan bermakna antara siklus menstruasi pada penggunaan AKDR dan siklus menstruasi penggunaan alat kontrasepsi suntik.

\section{PEMBAHASAN}

1. Siklus menstruasi pada penggunaan AKDR

Siklus menstruasi ialah jarak antara tanggal mulainya menstruasi yang lalu dan mulainya menstruasi berikutnya. Hari mulainya perdarahan dinamakan hari pertama siklus. Karena jam mulainya menstruasi tidak diperhitungkan dan tepatnya waktu keluar menstruasi dari ostium uteri eksternum tidak dapat diketahui. Oleh karena itu dalam penelitian ini siklus menstruasi dihitung dengan satuan hari. Pada penelitian ini ditemukan rentang siklus menstruasi pada akseptor AKDR yaitu $12-28$ hari. Panjang siklus menstruasi yang normal atau dianggap sebagai siklus menstruasi yang klasik ialah 28 hari. Rata-rata panjang siklus menstruasi pada gadis 12 tahun ialah 25,1 hari, pada wanita usia 43 tahun 27,1 hari, dan pada wanita usia 55 tahun 51,9 hari. Berbagai faktor seperti faktor hormon, vaskuler, enzim, dan prostaglandin bisa mempengaruhi siklus menstruasi sehingga siklus menstruasi akan berbeda antara wanita satu dengan wanita yang lain. Siklus kurang dari 21 hari 
disebut juga polimenore dan siklus lebih dari 35 hari disebut juga oligomenore, dan siklus normal antara 21-35 hari. Sedangkan siklus yang memanjang atau kadang tidak terjadi menstruasi selama minimal 3 bulan berturut-turut dinamakan amenore. Jadi, sebenarnya panjang siklus menstruasi 28 hari itu tidak sering dijumpai. (Wiknjosastro, 2008)

Pada siklus menstruasi pengguna AKDR didapatkan hasil mayoritas responden berada dalam kategori siklus normal yaitu 17 responden (58.62\%). Hal ini sesuai dengan teori menurut Mielani (2010) yang menyatakan salah satu keuntungan pemakaian AKDR adalah tidak ada interaksi obat (dalam hal ini hormon) sehingga tidak mengganggu fungsi tubuh dan hormonal sehingga tidak menimbulkan perubahan pada siklus menstruasi, karena siklus menstruasi sangat berkaitan dengan hormon terutama hormon reproduksi. Akan tetapi pada penelitian ini juga didapatkan hasil bahwa pada pemakaian AKDR didapatkan sebanyak 5 responden (26.31\%) mengalami polimenore, yaitu siklus menstruasi yang lebih pendek yaitu kurang dari 21 hari. Hal ini menurut Mielani (2010), dikarenakan kerugian pemakaian AKDR salah satunya adalah perubahan siklus haid yaitu perdarahan yang umumnya terjadi pada 3 bulan pertama dan akan berkurang setelah 3 bulan, haid lebih lama dan banyak, perdarahan antar menstruasi, dan saat haid lebih sakit. $\mathrm{Hal}$ ini disebabkan karena AKDR yang dianggap benda asing oleh tubuh sehingga mengakibatkan perubahan pada tuba dan cairan uterus. Perubahan pada tuba dan cairan uterus ini juga menyebabkan perdarahan yang sering terutama pada 3 bulan pertama sehingga pada siklus menstruasi pengguna AKDR ini tidak ditemukan siklus yang memanjang atau oligomenoreamenore.

Berdasarkan karakteristik umur responden maka sebagian besar responden pengguna AKDR adalah 25-30 tahun yaitu sebesar $50 \%$. Hal ini bisa dijelaskan bahwa usia tersebut termasuk dalam usia reproduksi sehat. Pada masa tersebut dimungkinkan Pasangan Usia Subur (PUS) sedang dalam masa menjarangkan jarak kelahiran sehingga alat kontrasepsi pilihan yang ideal adalah AKDR dimana keuntungan pemakaiannya adalah tidak mempengaruhi kesuburan.

Berdasarkan karakteristik lama pemakaian maka sebagian besar responden memakai AKDR antara 5-10 tahun. Hal ini dikarenakan AKDR dapat dipakai dalam jangka waktu yang lama. Menurut Everett (2007), nama dan rincian AKDR yang saat ini masih digunakan yaitu T $380 \mathrm{~A}$ yang bisa digunakan selama 8 tahun dan Nova $T$ yang bisa digunakan sampai 5 tahun.

2. Siklus menstruasi pada pengguna alat kontrasepsi suntik

Menurut hasil penelitian diketahui bahwa pada pemakaian alat kontrasepsi suntik didapatkan hasil sebagian besar responden mempunyai siklus menstruasi polimenore yaitu siklus menstruasi yang lebih pendek kurang dari 21 hari, sebanyak 12 responden (54.50\%). Hal ini sesuai dengan teori yang dikemukakan oleh Wiknjosastro (2008), bahwa banyak faktor yang mempengaruhi perubahan siklus menstruasi seorang wanita, salah satunya adalah faktor hormonal 
seperti yang terkandung dalam alat kontrasepsi suntik. Kandungan hormon esterogen dan progesteron yang terkandung dalam alat kontrasepsi suntik bisa mempengaruhi siklus menstruasi pengguna sehingga menyebabkan perdarahan yang sering sampai spoting atau bercak darah saja. Karena seringnya perdarahan menyebabkan siklus menstruasi memendek atau disebut dengan siklus polimenore sehingga pada pemakaian alat kontrasepsi suntik ini tidak ditemukan siklus menstruasi yang memanjang atau oligomenore-amenore. $\mathrm{Hal}$ ini juga sesuai dengan teori menurut Meilani (2010), yang menyatakan salah satu efek samping dari pemakaian alat kontrasepsi suntik adalah perdarahan yang banyak ataupun sedikit, perdarahan tidak teratur ataupun perdarahan bercak, atau tidak haid sama sekali.

Berdasarkan karakteristik responden menurut umur maka diketahui bahwa mayoritas pengguna alat kontrasepsi suntik berusia 30-35 tahun dimana pada masa tersebut masih termasuk usia reproduksi sehingga penggunaan alat kontrasepsi yang bisa digunakan adalah alat kontrasepsi suntik. Hal ini dikarenakan penggunaan alat kontrasepsi ini bisa efektif menjarangkan kehamilan.

Sedangkan dilihat dari karakteristik responden berdasarkan lama pemakaian maka didapatkan hasil bahwa sebagian responden pengguna alat kontrasepsi suntik sudah menggunakan selama 0-5 tahun. Temuan ini berbeda dengan lama pemakaian pada AKDR dan hal ini dikarenakan pada penggunaan alat kontrasepsi suntik jangka panjang akan terjadi defisiensi estrogen sehingga dapat menyebabkan kekeringan vagina, menurunkan libido, gangguan emosi, sakit kepala, jerawat dan meningkatkan risiko osteoporosis.

3. Perbedaan siklus menstruasi antara ibu yang menggunakan AKDR dan alat kontrasepsi suntik Dari hasil analisis statistik diperoleh nilai $p$ sebesar 0,032 yaitu kurang dari 0,05 maka Ho ditolak dan Ha diterima. Dengan demikian didapatkan suatu kesimpulan bahwa terdapat perbedaan yang secara statistik bermakna pada siklus menstruasi antara ibu yang menggunakan Alat Kontrasepsi Dalam Rahim dengan kontrasepsi suntik di Desa Beruk Kabupaten Karanganyar. Dari nilai ratarata yang diperoleh, siklus menstruasi pada ibu yang menggunakan Alat Kontrasepsi Dalam Rahim sebesar 26 hari dengan dengan standar deviasi 4.86. Sedangkan nilai rata-rata siklus menstruasi pada ibu yang menggunakan alat kontrasepsi suntik sebesar 19 hari dengan standar deviasi 4.55. Dengan hasil tersebut, dapat dinyatakan bahwa siklus menstruasi pada ibu yang menggunakan AKDR lebih baik dibandingkan dengan ibu yang menggunakan alat kontrasepsi suntik karena lebih mendekati siklus menstruasi klasik yaitu 28 hari. Menurut hasil analisis ini secara nyata siklus menstruasi antara ibu di Desa Beruk Kabupaten Karanganyar berbeda menurut jenis alat kontrasepsi yang digunakan. Hasil penelitian ini sesuai dengan penelitian Murdiyanti dan Inda (2009) dengan hasil bahwa terdapat perbedaan yang signifikan siklus menstruasi antara ibu yang menggunakan IUD dengan kontrasepsi suntik di Geneng Sentul Sidoagung Godean Sleman Yogyakarta. 
Hasil penelitian ini juga sama dengan penelitian oleh Puji Lestari (2013) yang menyatakan terdapat perbedaan menstruasi antara akseptor IUD dan akseptor suntik 1 bulan.

Menstruasi didefinisikan sebagai perdarahan pervaginam yang terjadi selama 1 episode setiap siklus. Menurut Meilani (2010), AKDR merupakan kontrasepsi yang dimasukkan melalui serviks dan di pasang di dalam uterus. AKDR memiliki benang yang menggantung sampai liang vagina. AKDR mencegah kehamilan dengan merusak kemampuan hidup sperma dan ovum karena adanya perubahan pada tuba dan cairan uterus. Tembaga yang dililitkan pada AKDR bersifat toksin terhadap sperma dan ovum. Cara kerja inilah yang membuat AKDR efektif mencegah kehamilan tetapi tidak mempengaruhi siklus menstruasi, berbeda dengan alat kontrasepsi suntik yang mengandung hormonal.

\section{KESIMPULAN}

Berdasarkan pembahasan di atas dan berdasarkan hasil uji statistik dengan menggunakan uji Mann Withney dengan menggunakan SPSS versi 18 didapatkan hasil nilai $\mathrm{p}$ sebesar 0,030 yaitu kurang dari 0,05 maka $\mathrm{Ho}$ ditolak dan $\mathrm{Ha}$ diterima. Dengan demikian didapatkan suatu kesimpulan bahwa terdapat perbedaan yang bermakna secara statistik pada siklus menstruasi antara ibu yang menggunakan Alat Kontrasepsi Dalam Rahim dengan kontrasepsi suntik di Desa Beruk Kabupaten Karanganyar.

Rata-rata siklus yang terjadi pada penggunaan AKDR adalah 23.91 hari dengan standar deviasi 4.86 sedangkan rata-rata siklus yang terjadi pada penggunaan alat kontrasepsi suntik adalah 21.08 hari dengan standar deviasi 4.8. dengan demikian siklus menstruasi pada penggunaan alat kontrasepsi suntik karena lebih mendekati siklus klasik 28 hari.

\section{SARAN}

Berdasarkan hasil penelitian dan kesimpulan di atas maka disarankan para calon pengguna alat kontrasepsi untuk memprioritaskan penggunaan AKDR daripada alat kontrasepsi suntik untuk mengurangi risiko gangguan terhadap siklus menstruasi yang mungkin terjadi. Selain itu bagi penyedia layanan penggunaan alat kontrasepsi diharapkan untuk memberikan konseling tentang alat kontrasepsi serta kelebihan dan kekurangannya terlebih dahulu sehingga akseptor mampu memilih dan memutuskan alat kontrasepsi yang sesuai.

Bagi peneliti selanjutnya diharapkan untuk dapat melakukan penelitian sejenis dengan memperbanyak variabel yang diteliti terkait banyaknya faktor yang dapat mempengaruhi siklus menstruasi selain penggunaan alat kontrasepsi.

\section{DAFTAR PUSTAKA}

Ariani, Ayu Putri. Aplikasi Metodologi Penelitian Kebidanan dan Kesehatan Reproduksi. Yogyakarta: Nuha Medika, 2014.

Everett, Suzanne. Buku Saku Kontrasepsi dan Kesehatan Seksual Reproduktif. Edisi 2. Alih bahasa Nike Budhi Subekti. Jakarta: EGC, 2007.

$\begin{array}{cr}\text { Handayani, } & \text { Sri. } \\ \text { Pelayanan } & \text { Keluarga } \\ \text { Berencana. } & \text { Yogyakarta: } \\ \text { Pustaka Rihama, } 2010 .\end{array}$


Hidayat, A. Aziz Alimul. Riset Keperawatan dan Teknik Penulisan IImiah. Jakarta: Salemba Medika, 2008.

Metode Penelitian Kebidanan dan Teknik Analisa Data. Jakarta: Salemba Medika, 2009.

Hidayati, Ratna, et al. Praktik Laboratorium Keperawatan. Jakarta: Erlangga, 2014.

Kusmiran, Eny. Kesehatan Reproduksi Remaja dan Wanita. Jakarta: Salemba Medika, 2012.

Meilani, Niken, et al. Pelayanan Keluarga Berencana (dilengkapi dengan penuntun belajar). Yogyakarta: Fitramaya, 2010.

Sulistiyawati, Ari. Pelayanan Keluarga Berencana. Jakarta: Salemba Medika, 2012.

Wiknjosastro, Hanifa, Abdul Bari Saifuddin dan Trijatmo Rachimhadhi, ed. IImu Kandungan. Edisi II. Jakarta: PT Bina Pustaka Sarwono Prawirohardjo, 2008.

Lestari, Puji Erna. Perbedaan Menstruasi Antara Akseptor $K B$ yang Menggunakan Kontrasepsi IUD dengan Kontrasepsi Suntik 1 Bulan di Desa Bajang Balong Ponorogo. 2013.
Murdiyanti Dewi dan Indah Melaning Putri. Perbedaan Siklus Menstruasi Antara lbu yang Menggunakan Alat Kontrasepsi IUD Hipokotil Kontrasepsi Suntik di Dusun Geneng Sentul Sidoagung Godean Sleman Yogyakarta. 2009.

Sudibyo, Prediksi BKKBN:2011, Penduduk Indonesia 214 juta. 2011.

1 Dosen AKPER Panti Kosala Surakarta

2 Mahasiswa AKPER Panti Kosala Surakarta

3 Mahasiswa AKPER Panti Kosala Surakarta 